\title{
Immediate implant placement in the infected sockets - A case series
}

\author{
Aeklavya Panjali* \\ Director, New York Implant Institute, 140 Eastern Blvd, Watertown, New York 13601, USA
}

\begin{abstract}
The question whether an implant could be placed in an infected site has often been raised and addressed in the literature by several authors. There are several studies that have successfully placed implants in infected sites [1-6]; however, all these studies removed granulation tissue before placing the implant as a part of their clinical protocol [7-16]. In this study, the implants were placed in infected sites without curettage.

A prospective clinical study was done with a total of 10 cases. The selected infected, maxillary anterior teeth presented with either chronic or acute periapical lesions with poor to a hopeless prognosis. A standardized surgical and prosthetic protocol was developed. Implants were placed and cases were evaluated at six-month follow-up. Using pre- and postoperative cone beam computed tomography (CBCT), data were collected [16-22]. The result reflects and confirms the hypothesis that endosteal implants can be successfully integrated in infected sites. However, alveolar ridge resorption after the tooth extraction is a frequent occurrence and may significantly reduce the residual bone volume [23-28]. This study is a proof of principle that sockets can heal naturally with immediately placed implants in infected sites and tissue shrinkage can be reduced by utilizing least invasive surgical and prosthetic protocol.
\end{abstract}

\begin{abstract}
Abbreviations: et al.: Et alii (latinum) in English is"and others"; mm: Millimeters; n: Number; CBCT: Cone beam computed tomography; FGM: Free gingival margin; CCL: Clinical Crown Length; GBR: Guided bone regeneration; GTR: Guided tissue regeneration; ASA: American Society of Anesthesiologists; RCT: Root canal treatment; rpm: Revolution per minute; Ncm: Newton centimeters (measures torque); ISQ: International System of Quantities
\end{abstract}

\section{Introduction}

In 1989, Lazzara [6] first reported immediate implant placement in an extraction socket in humans. Since then, this treatment modality has received much attention in the literature [13] Fugazzotto [25] conducted the only study comparing implants immediately placed into sites with periapical pathology with those immediately placed into sites without periapical pathology in the same patient, thus helping to control a number of interpatient variables and render the results more directly clinically applicable. It was observed that both treatments yielded comparable results with no statistically significant difference in survival rates. Bell and colleagues [28] immediately placed 285 implants into sockets that had chronic periapical infections (with seven failures) and 637 implants into extraction sites that were not affected by periapical radiolucencies (with eight failures). The difference between the control group and the group with periapical radiolucency was not statistically significant. Therefore, the only disadvantage of the placement of implants into fresh extraction sockets with periapical lesions is that it can potentially contaminate implant during the initial healing period because of remnants of the infection [2-6]. Infected, non-restorable teeth are indicated for extraction, and immediate replacement with endosseous dental implant is contraindicated 8 due to the risk of microbial interference with the healing process [29-32]. Some studies on immediate implants suggest that periapical or periodontal pathosis should not be performed [33-35]. In addition, there are clinical reports suggesting that the history of periodontal or endodontic infections is a predictive marker for implant infection and failure [9,34]. The presence of chronic periodontal disease has also been correlated with an increased risk of implant failure [31,36-40]. Therefore, infected sites are considered as a contraindication for immediate implantation by many clinicians [14]. Maxillary alveolar process is dependent on the existence of teeth. This area will undergo significant structural changes when teeth are lost. The dynamics and magnitude of these changes can be very significant if there is infection present. The biological process occurring after the tooth extraction produces a physiological resorption of the alveolar process and, consequently, a reduction in volume of the maxillary bone, which usually affects the vestibular side of the bone crest. In the first three months following an extraction, there will be a horizontal volume reduction of $30 \%$ of the alveolar process, which could reach up to $50 \%$ in 12 months (Schropp et al., 2003).

Following tooth extraction, the periodontal ligament (PDL) loses its functionality and disappears. However, the remnants of PDL cells differentiate into a variety of cell types, including fibroblasts, osteoblasts, and osteoclasts [41-43]. There are a few studies that suggest that PDL fibroblasts have osteoblast-like properties [44,45]. Lin, et al. [46] found that PDL fibroblasts actively proliferate after the tooth extraction, migrate into the coagulum, form dense connective tissue, and differentiate into the osteoblasts that form new bone during socket healing. Therefore, the state of the PDL and the remaining socket wall would be the main influential factors for the osseous regeneration. Diseased sockets will often present with vital and some non-vital

Correspondence to: Aeklavya Panjali DDS, MSc, Director, New York Implant Institute, 140 Eastern Blvd, Watertown, New York 13601, USA, Tel: 315-7798080, E-mail: drpanjali@yahoo.com

Received: January 18, 2017; Accepted: February 01, 2017; Published: February 03,2017 
bone. The presence of vital or non-vital bone fragments, which appear separately from the host bone, were found in diseased sockets only [47]. These might be regarded as fragments that had detached from the host bone as a consequence of chronic irritation from bacterial toxins [47]. New woven bone and active osteoid were found to form on these isolated bone fragments. Therefore, vital or non-vital bone fragments might play an important role like a nucleus of ossification, or they might serve as autogenous bone graft in the healing process [47]. Accordingly, it is cautiously suggested that unnecessary instrumentation in the extraction site might result in the removal of these advantageous vital or non-vital bone fragments and could diminish the healing potential of the surrounding walls [47].

The purpose of this study was to establish the treatment outcomes of immediate implant placement into the infected sites without decontaminating the extraction sockets, raising the following questions: Does the presence of periodontal or endodontic infection affect the outcome of immediate implant placement? Will implants osseointegrate when the sockets are left un debrided and un curretaged? What are the changes that will occur in the soft tissue volume, bone volume, and total tissue volume surrounding these implants? Lastly, whether the facial bone regenerates naturally after the bundle bone disappears, and, if yes, is the growth limited to horizontal fill or is it possible to gain height too?

This study will establish that osseointegration can be achieved without treating the infected socket, and the surrounding tissue including the surrounding bone and the soft tissue will undergo less shrinkage with immediate implant placement compared to sockets receiving no treatment whatsoever.

\section{Material and methods}

A prospective clinical study was done with a total of 10 cases. The selected infected, maxillary anterior teeth presented with either chronic or acute periapical lesions with poor to a hopeless prognosis. Consents were reviewed with the patients discussing the risks, benefits, and alternate treatments with the option of do nothing. A standardized surgical and prosthetic protocol was developed. Implants were placed and cases were evaluated at six-month follow-up. Using pre- and postoperative cone beam computed tomography (CBCT), data were collected.

\section{Data extraction:}

The following questions were raised and will be discussed:

1. Does the presence of periodontal or endodontic infection measuring $<5 \mathrm{~mm}$ (in maximum diameter) compromise the success of immediate implant placement?

2. What is advised to combat the socket infection prior to immediate placement?

3. What tissue preservation/maintenance effects/results could be achieved by preserving the post-extraction biological and structural anatomical environment?

4. What will be the fate of the labial plate and overlying soft tissue over time?

5. Anatomical and structural variations/effects of unfilled gap distance after six months.

6. Effects of using the palatal plate as reference for subcrestal immediate implant placement irrespective of the length of intact facial plate.

\section{Surgical strategies and protocol:}

\section{Inclusion criteria:}

- ASA II,

- age $>18$ years,

- non-restorable periapical infected site in maxillary anterior teeth,

- written informed consent,

- only partially edentulous patients in general good health.

Eligibility criteria included implant placement into the site classified as having clinical and/or radiological signs of an infection, being periapical as in endodontic lesion, which includes the following:

- formation of a periapical abscess,

- pulpal necrosis,

- presence or not of an intraoral opening of a sinus tract,

- periapical radiolucency,

- root fracture,

- external root resorption,

- failed apicectomy,

- $\quad$ failing retreated RCT

Perio-endodontic lesions that include the following:

- presence of acute inflammation of the periodontal ligament,

- pulpal necrosis,

- isolated deep pockets and circumradicular/interradicular radiolucency,

- indicating an osseous defect along the PDL from apical to coronal.

Periodontal Lesions that include the following:

- clinical signs of acute/chronic inflammation of the gingiva, periodontal attachment structures, and alveolar bone, periodontal pockets,

- periodontal abscess may or may not be present,

- loss of both the attachment of the PDL and bony support,

- decreased vertical height of the bone surrounding the affected teeth.

\section{Exclusion criteria:}

- ASA III,

- patients with systemic diseases like uncontrolled diabetes mellitus, bisphosphonate therapy, and thyroid therapy will not be included,

- restorable tooth.

\section{Surgical protocol}

\section{Treatment protocol:}

- No antibiotic prophylaxis. 
- Consent to treatment discussed and signed by patients.

- Atraumatic extraction using periotomes, luxators, and forceps.

- No debridement or curettage to be done post-extraction.

- Implant system: platform switched, sealed conical connection, progressive thread design.

- Implant placement:subcrestal placement with palatal plate as a reference, and the implant will be directed palatally.

- Prosthetic protocol: A final abutment with deep crown margin is seated and temporary crown is fabricated on master cast (no intraoral relining). Socket sealing with the lined extracted tooth or with the polycarbonate crown is done.This provisional restoration is then cemented extraorally on an abutment replica wherein the excess cement is removed and then cemented intraorally. There will be no functional occlusion, no splinting to neighboring teeth.

Patients presented with non-restorable teeth, and these teeth were extracted for the following reasons:

- Vertical fractures-six teeth.

- External root resorption-two teeth.

- Severe periodontitis with Grade II mobility—one tooth.

- Failed endodontic treatment with hopeless prognosis-one tooth.

All antibiotics and anti-inflammatory medications were stopped 3-4 weeks prior to surgery. Pre-op-cone-beam using Galileo (Sirona) were used. No surgical guides were fabricated, and all surgeries were done under local anesthesia ( $2 \%$ lidocaine with 1:100,000 epinephrine). Dissection of gingival fibers utilizing a $12 \mathrm{C}$ blade was given to gain access to the PDL space. Periotome-assisted atraumatic extraction was done. Osteotomy was performed at $700 \mathrm{rpm}$ with normal saline external irrigation, $3 \mathrm{~mm}$ coronal from the apex on the palatal side of the socket without debridement and or alteration of any kind. Final drill measuring $2.8 \mathrm{~mm}$ was used, and the implant (Megagen $3.5 \mathrm{~mm}$ wide) was torqued at $35 \mathrm{Ncm}$. The implant was placed $2-3 \mathrm{~mm}$ subcrestal to the palatal wall and ISQ recorded 70 and above. If the ISQ was lower than 70 , then the implant was given another half or full turn to achieve the ISQ value of 70 . Stock abutments were prepped extraorally and placed at $20 \mathrm{Ncm}$ measured (Mega Torque). Provisional restoration was fabricated using prefabricated polycarbonate crowns with acrylic resin and extended $2-3 \mathrm{~mm}$ subgingival from the facial free gingival margin to seal the socket and maintain the space. All restorations were left out of occlusion in centric as well as protrusive for a period of eight weeks. No grafting and no modifications were made to the sockets. Patients were on recall as follows: 1-week, 4-week; 8-week and 6-month follow-up appointments. ISQ measurements and CBCT were taken at asix-month period to evaluate osseointegration and tissue changes.

\section{Data collection}

Preoperative consent forms, CBCT, digital impression with Planmeca Romexis were taken in addition to the physical examination. The results were compared one year later to the initial data

\section{Preoperative}

- Pain

- Inflammation
- Suppuration or discharge

- $\quad$ Pocket depths

- Cone-beam CT-measures length and width of the bone at the crest with free gingival margin (FGM) being the reference

- Intraoral photos

- Impression (intraoralscan) to measure tissue thickness

\section{Postoperative}

- Pain

- Inflammation

- Osstell readings

- Discharge

- Post healing:4-8 week

- $\quad$ Post-prosthetic rehabilitation: 14-18 weeks

- Cone-beam CT (one year)-measures length and width (implant-mid section) of the bone at the crest with FGM being the reference

- Intraoral photos

- Impression (intraoralscan) to measure tissue thickness

A radiologist double-checked the $\mathrm{CBCT}$ readings. Bone height measurements were taken with FGM as a reference pointand the FGM was measured taking the clinical crown length (CCL) as a reference.

\section{Data analysis/statistical methods}

The implants placed in this study have been functional for over 18-20 months with good esthetics, function, and form maintained since last examination, which was performed after a year of implant placement. All patients are committed to return for evaluations every six to eight months so that a proper follow-up and long-term outcomes, success rate, and survival of these implants can be documented.

Failure and complication rates were calculated by dividing the number of failures or complications by the total time of placed implants.

$\mathrm{x}$-year survival proportions were calculated via the relationship between event rate and survival function $\mathrm{S}(\mathrm{T})$ by assuming constant event rates.

$\mathrm{S}(\mathrm{T})=\exp (-\mathrm{T} \times$ event rate $)$

A descriptive analysis was performed.

All statistical tests were performed in R (v3.1) at alpha 0.05 .

$\mathrm{R}$ is statistical software, which was used to perform $\mathrm{t}$-test and construct all the graphs. v3.1 is the version of this software used for this analysis.

\section{All statistical tests were performed in $R$ (v3.1) at alpha 0.05}

$\mathrm{R}$ is statistical software, which was used to perform t-test and construct all the graphs provided earlier. v3.1 is the version of this software used for this analysis.

pValue was determined in the following manner

Alpha $=0.05$ 
$\mathrm{H} 0=$ null hypothesis.

$\mathrm{Ha}=$ alternate hypothesis.

$\mathrm{N}=9$

\section{Results}

\section{Subjects:}

Of the 10 patients, $6(60 \%)$ subjects were males and $4(40 \%)$ were females (Figure 1).

\section{Implant survival:}

As far as the final result is concerned $(n=9 / 10)$, there is $90 \%$ success in osseointegration (Figure 2).

\section{Failures:}

There was one failed implant, subject F6. This was the only failure in the study observed when the patient came for four weeks'postoperative checkup. During the test for mobility, patient was extremely sensitive when reverse torque was applied. There was radiolucency and frank mobility, which allowed easy implant removal (Table 1).

\section{Average Shrinkage Bucco-Lingually:}

The results of this study indicate that the average shrinkage buccolingually was $17 \%$. Five out of the nine surviving implants showed very minimal shrinkage (Figure 2). Subjects C7,C8, and D7 had the most shrinkage with average of $1-1.8 \mathrm{~mm}$, and there was one subject, $\mathrm{H} 8$, that gained bone by $1.02 \mathrm{~mm}$.

\section{Bucco-lingual width:}

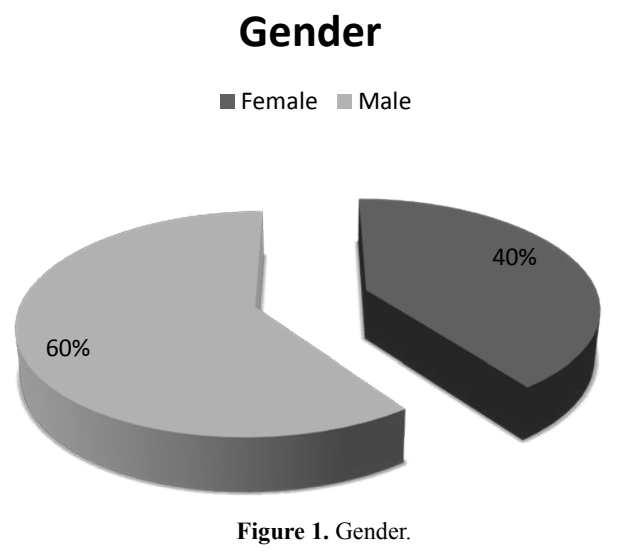

\section{Success}

- Osseointegration $\square$ Failure

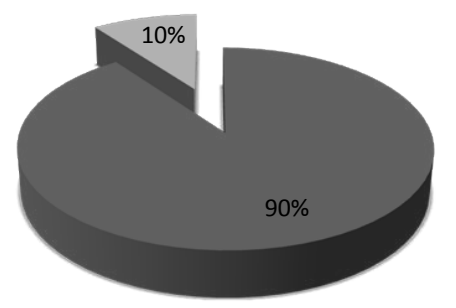

Figure 2. Implant survival (success rate).

\begin{tabular}{|c|c|}
\hline Subject & F6 \\
\hline Gender & Male \\
\hline Region & $\# 6$ \\
\hline Week of failure & Fourth week after the implant insertion \\
\hline Type of prosthetics & None \\
\hline Radiolucency & Yes \\
\hline Mobility & Yes \\
\hline
\end{tabular}

Table 1. Implant failure.

\begin{tabular}{|c|c|c|c|c|}
\hline SUBJECT & CODE & SEX & TOOTH \# & SUCCESS \\
\hline VR & A8 & M & 8 & Y \\
\hline JR & B6 & M & 6 & Y \\
\hline JR & B7 & M & 7 & Y \\
\hline MIV & C7 & F & 7 & Y \\
\hline MIV & C8 & F & 7 & Y \\
\hline PK & D7 & F & 7 & Y \\
\hline BM & E9 & M & 9 & Y \\
\hline PT & F6 & M & 6 & N \\
\hline WJ & G8 & M & 8 & Y \\
\hline LB & H8 & F & 8 & Y \\
\hline
\end{tabular}

Figure 3. Subjects.

H0: Change in width $=0$

Ha: Change in width $<0$

Standardized t-test gives us significant evidence $(\mathrm{p}=0.01)$ of an overall decrease in bucco-lingual width $(n=9)$. All statistical tests were performed in R (v3.1) at alpha 0

\section{Outcome of FGM to lingual and to facial:}

FGM is taken as a reference point to determine changes in length of the facial bone and palatal bone. The CCL was measured at implant placement and re-measured after a one-year follow-up. The difference in the length (CCL) was recorded equal to or less than the initial reading in $90 \%$ of the cases. The decrease in CCL in these $90 \%$ cases was 0.013 $\mathrm{mm}$ on average, and the only significant decrease was noticed in one case by $1.03 \mathrm{~mm}$. All measurements were performed by digital vernier caliper. CCL was referenced to the position of the FGM, which, in turn, was used as a reference point to measure the height of the bone both palatal and facially. As seen in figure 3, there are four out of nine cases where there is a decrease in the length between FGM and facial bone crest with an average loss of lengthrecorded at $0.16 \mathrm{~mm}$. Similarly, the average obtained between FGM and palatal crest is $0.26 \mathrm{~mm}$ (Figure 4).

\section{FGM to lingual:}

H0: Change in width $=0$

Ha: Change in width $>0$

Standardized t-test gives us significant evidence $(\mathrm{p}=0.7262)$ of no change in FMG to lingual width $(n=9)$.

\section{FGM to facial:}

H0: Change in width $=0$

Ha: Change in width $>0$

Standardized t-test gives us significant evidence $(\mathrm{p}=0.59)$ of no change in FMG to facial width $(\mathrm{n}=9)$.

\section{Outcome of tissue width:}

Tissue width was measured at the crestal area from facial to the palatal side including the soft tissue. Figure 5 indicate the changes with an average decrease in width by $1.07 \mathrm{~mm}$.

Tissue width (B-L): 
Bucco-lingual width (crest to crest)before and after placement of implant

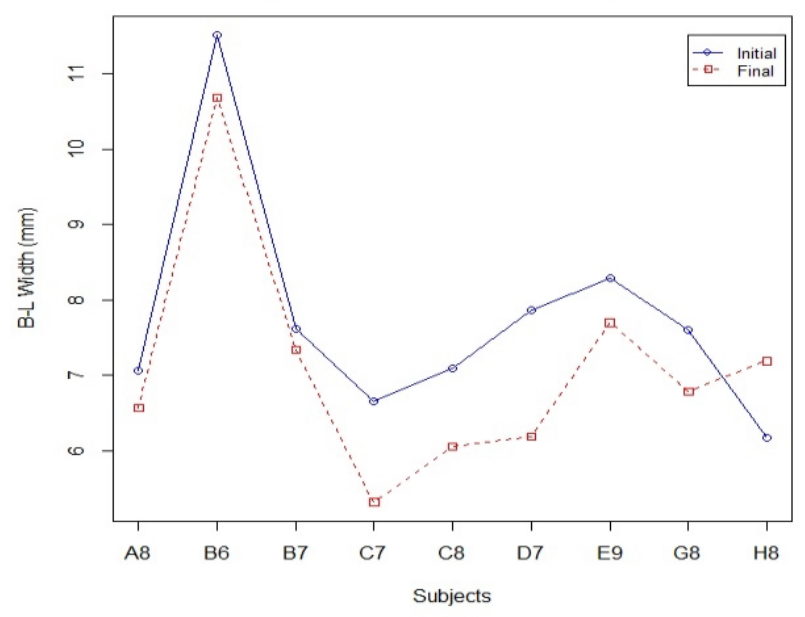

Figure 4. Bucco-lingualwidth crest.

B-L width crest to crest $(\mathrm{mm})$ before and after placement

\begin{tabular}{|c|c|c|c|}
\hline Subjects & Initial & Final & Change \\
\hline A8 & 7.07 & 6.57 & -0.5 \\
\hline B6 & 11.51 & 10.68 & -0.83 \\
\hline B7 & 7.62 & 7.34 & -0.28 \\
\hline C7 & 6.66 & 5.32 & -1.34 \\
\hline C8 & 7.1 & 6.06 & -1.04 \\
\hline D7 & 7.86 & 6.19 & -1.67 \\
\hline E9 & 8.29 & 7.7 & -0.59 \\
\hline G8 & 7.6 & 6.79 & -0.81 \\
\hline H8 & 6.17 & 7.19 & 1.02 \\
\hline \hline AVERAGE & $\mathbf{7 . 7 6}$ & $\mathbf{7 . 0 9}$ & -0.67 \\
\hline
\end{tabular}

Figure 5. Bucco-lingual width crest to crest.

H0: Change in width $=0$

Ha: Change in width $<0$

Standardized t-test gives us significant evidence $(\mathrm{p}=0.05)$ of no change in tissue width $(\mathrm{n}=9)$.

\section{Outcome of facial bone width:}

Facial bone width is by far the most significant finding in this study as it shows an increase in width of the bone in $60 \%$ of the cases with an overall average increase in width by $0.36 \mathrm{~mm}$ (Figure 6).

\section{Facial bone width:}

H0: Change in width $=0$

Ha: Change in width $<0$

Standardized t-test gives us significant evidence $(\mathrm{p}=0.88)$ of no change in facial bone width $(n=9)$.

\section{Outcome of mesial and distal crestal bone changes:}

Mesial and distal crestal bones were not measured in this study; however, the pocket depths were decreased by $1 \mathrm{~mm}$ in all cases (Figure 7).

\section{Discussion}

The result reflects and confirms the hypothesis that endosteal implants can be successfully integrated in infected sites. However, alveolar ridge resorption after the tooth extraction is a frequent occurrence and may significantly reduce the residual bone volume. This may affect the favorable positioning of implant, as well as the restoration, and warrant for additional tissue augmentation/ regeneration procedures after the final healing phase to produce a restoration that fulfills the criteria of restoring function, form, and esthetics.

The phenomenon of bone resorption is more pronounced in the anterior maxilla, where ridge resorption often creates an unfavorable palato labial discrepancy between the implant and the prosthesis [2]. Horizontal reductions of up to $50 \%(5-7 \mathrm{~mm})$ were observed during the first year following single tooth extraction [3]. Several studies have suggested that in an effort to minimize the alveolar bone resorption and collapse caused during the initial healing phase (Figure 8), it is sometimes advisable to place an implant immediately into the extraction socket, without waiting for the site to heal. This not only reduces the treatment time [14], number of surgeries, and fulfills patient's esthetic need but also reduces the postoperative volumetric shrinkage occurring in the surgical site (Figure 9). However, the results of this study indicate that the average shrinkage bucco-lingually was $17 \%$ compared to $30-50 \%$ suggested by Schropp, et al. (2003). Five out of the nine surviving implants showed very minimal shrinkage (Figure



Figure 6. FGM to facial crest.

FGM to facial crest ( $\mathrm{mm}$ ) before and after placement

\begin{tabular}{|c|c|c|c|}
\hline Subjects & Initial & Final & Change \\
\hline A8 & 2.17 & 4.49 & 2.32 \\
\hline B6 & 2.6 & 2.01 & -0.59 \\
\hline B7 & 2.29 & 4.14 & 1.85 \\
\hline C7 & 3.27 & 3.59 & 0.32 \\
\hline C8 & 3.39 & 3.12 & -0.27 \\
\hline D7 & 2.37 & 3.44 & 1.07 \\
\hline E9 & 3.3 & 2.97 & -0.33 \\
\hline G8 & 10.65 & 6.05 & -4.6 \\
\hline H8 & 5.67 & 4.5 & -1.17 \\
\hline \hline AVERAGE & $\mathbf{3 . 9 7}$ & $\mathbf{3 . 8 1}$ & -0.16 \\
\hline
\end{tabular}

Figure 7. FGM to facial crest before and after the placement. 
FGM to lingual crest $(\mathrm{mm})$ before and after placement

\begin{tabular}{|c|c|c|c|}
\hline Subjects & Initial & Final & Change \\
\hline A8 & 2.86 & 3.53 & 0.67 \\
\hline B6 & 1.76 & 2.3 & 0.54 \\
\hline B7 & 2.27 & 2.51 & 0.24 \\
\hline C7 & 4.13 & 1.9 & -2.23 \\
\hline C8 & 4.01 & 2.16 & -1.85 \\
\hline D7 & 3.18 & 4.08 & 0.9 \\
\hline E9 & 2.03 & 3.23 & 1.2 \\
\hline G8 & 3.04 & 1.84 & -1.2 \\
\hline H8 & 4.36 & 3.72 & -0.64 \\
\hline \hline AVERAGE & $\mathbf{3 . 0 7}$ & $\mathbf{2 . 8 1}$ & $-\mathbf{0 . 2 6}$ \\
\hline
\end{tabular}

Figure 8. FGM to lingual crest before and after the placement.

FGM to lingual crest before and after placement of implant

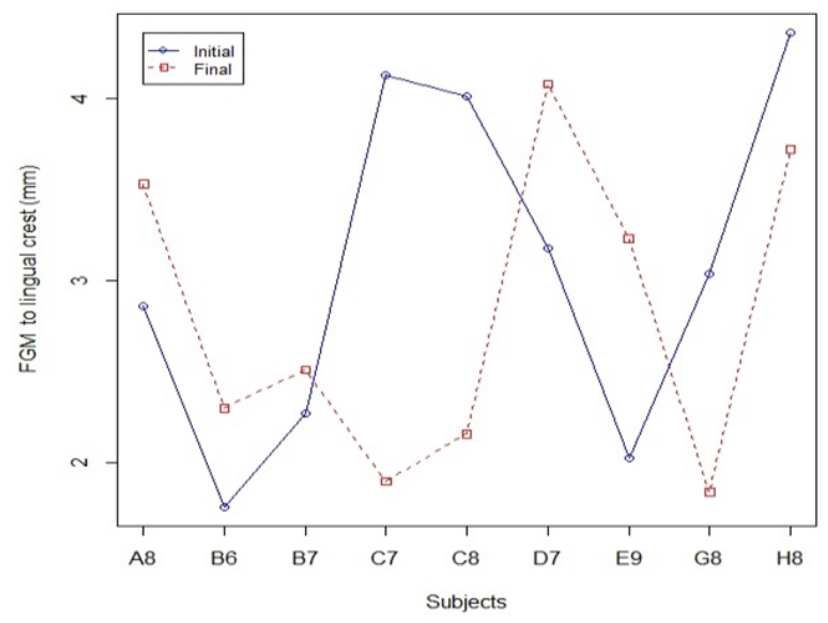

Figure 9. FGM to lingual crest before and after the implant placement.

1). Subjects $\mathrm{C} 7, \mathrm{C} 8$, and $\mathrm{D} 7 \mathrm{had}$ the most shrinkage with average of 1-1.8 $\mathrm{mm}$, and there was one subject, $\mathrm{H} 8$, that Gained bone by 1.02 $\mathrm{mm}$.

One implant failed in the fourth week after implant insertion. The reason for failure could not be determined; speculation could be made that functional forces destabilized primary stability and or the type of bacteria, and its virulence may have something to do with the failure. Although there was no functional occlusion at the time of placement, there could have been some unintentional micro-movement of some sort that could have disrupted the initial healing process. Therefore, a recommendation may be made regarding the role of the implant design, surface, and strength. The implants placed in the study were selected based upon the aggressive thread design and the coronal narrow, threadless portion that allowed more space for regeneration (Figure 10). Speculations can be made regarding the role of the implant design in achieving success; however, the fact that we need primary stability for immediate placement leads us to believe that there is some role that has been played by the implant itself in maintaining stability during the course of healing. The ISQ were measured at the time of placement and six months postoperative during the study, and there was an average increase of 5-8 units at the end of six months. The ISQ values were certainly low at the time of placement averaging 69 , and the torque values averaged between 45 and $50 \mathrm{Ncm}$, which ensured primary stability at the time of placement.

The soft tissue contours were maintained with minimal shrinkage of less than $1 \mathrm{~mm}$ in all cases. This resulting soft tissue contours were maintained with the help of provisional restoration fabricated at the time of surgery (Figure 11), and all the provisional restorations were extended subgingivally by $3 \mathrm{~mm}$ to support free gingiva and maintain the space between the soft tissue/facial bone and the implant. In other words, the gap distance was maintained and soft tissue collapse was prevented by the restoration itself, which helped maintain the space for tissue regeneration. The use of anatomically contoured provisional restorations may provide a platform to promote peri-implant soft tissue healing and minimize remodeling of the bucco-lingual ridge dimension [41].

The proposed protocol in this study is less invasive, does not require any addition of biomaterial, and results seem to be better than suggested in the literature as far as the volumetric changes are concerned. In addition, preserving the integrity of the socket walls may be essential in gaining better tissue regeneration (Figures 12 and 13), and therefore scraping, curettage, or similar procedures that can potentially damage the cells lining the socket walls should be prevented whenever possible.

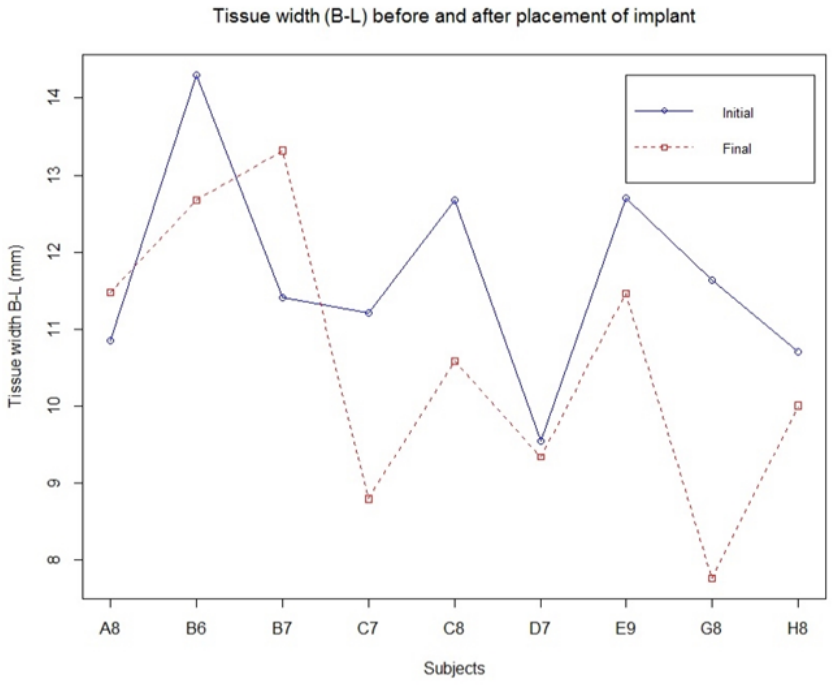

Figure 10. Tissuewidth in relation to the subject.

Tissue width B-L ( $\mathrm{mm}$ ) before and after placement

\begin{tabular}{|c|c|c|c|}
\hline Subjects & Initial & Final & Change \\
\hline A8 & 10.86 & 11.48 & 0.62 \\
\hline B6 & 14.3 & 12.68 & -1.62 \\
\hline B7 & 11.42 & 13.32 & 1.9 \\
\hline C7 & 11.21 & 8.79 & -2.42 \\
\hline C8 & 12.68 & 10.59 & -2.09 \\
\hline D7 & 9.55 & 9.34 & -0.21 \\
\hline E9 & 12.71 & 11.47 & -1.24 \\
\hline G8 & 11.64 & 7.76 & -3.88 \\
\hline H8 & 10.71 & 10.01 & -0.7 \\
\hline AVERAGE & 11.68 & 10.60 & -1.07 \\
\hline
\end{tabular}

Figure 11. Average of tissue width before and after the implant placement. 


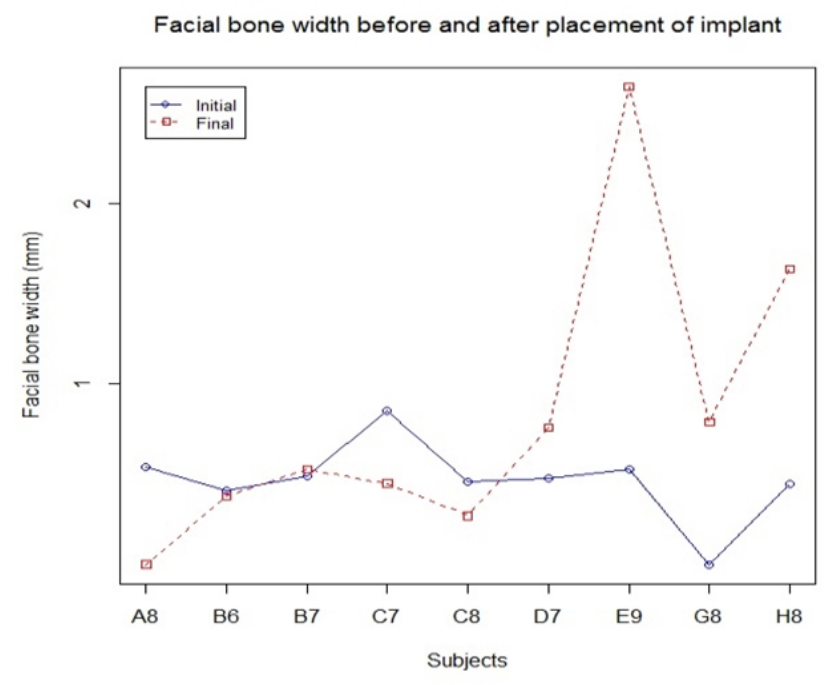

Figure 12. Facial bone width in relation to the subject.

Facial bone width $(\mathrm{mm})$ before and after placement

\begin{tabular}{|c|c|c|c|}
\hline Subjects & Initial & Final & Change \\
\hline A8 & 0.54 & 0 & -0.54 \\
\hline B6 & 0.41 & 0.38 & -0.03 \\
\hline B7 & 0.49 & 0.53 & 0.04 \\
\hline C7 & 0.85 & 0.45 & -0.4 \\
\hline C8 & 0.46 & 0.27 & -0.19 \\
\hline D7 & 0.48 & 0.76 & 0.28 \\
\hline E9 & 0.53 & 2.65 & 2.12 \\
\hline G8 & 0 & 0.79 & 0.79 \\
\hline H8 & 0.45 & 1.64 & 1.19 \\
\hline AVERAGE & $\mathbf{0 . 4 7}$ & $\mathbf{0 . 8 3}$ & $\mathbf{0 . 3 6}$ \\
\hline
\end{tabular}

Figure 13. Average of facial bone width.

\section{Conclusion}

Extraction of the involved tooth generally leads to eradication of the cultured microorganisms [15]. The natural healing process after the tooth extraction normally manages residual infection, but as the infection increases, the inflammatory activity or infection may result in increased bone resorption and a higher risk of implant stability loss and failure. The presence of granulation tissue in the socket of an infected tooth is usually an inflammatory response to bacteria. This reactive tissue protects bone from direct bacterial aggression and, if carefully removed, will reveal healthy bone. The drilling sequence of the osteotomy will often remove this granulation tissue preventing the need for unnecessary physical removal and socket curettage. This reduces the inflammatory response and the consequent bone resorption activity. Thus, the survival rate of immediate placement in infected sockets without curettage and decontamination compared to socket that are debrided is not significantly different. Most five-wall defects are can be treated utilizing this protocol with relative success.

The normal marginal bone changes obtained from several studies support the hypothesis that implants may be successfully osseointegrated when placed immediately after the extraction of teeth presenting endodontic and periodontal lesions, provided that appropriate clinical procedures are performed. The main criteria for immediate placement of an implant into a socket with periapical pathology should be the achievement of good primary implant stability, palatal placement, maintaining space for tissue regeneration and allowing for natural healing to occur. Since most periapical lesions are the result of inflammatory response, it is not necessary to use curettage, laser, or use medications to get rid of the inflammation because all three will disturb the natural cell environment in the socket and may inhibit cellular response. As observed in this study, there will be reduced tissue shrinkage associated with immediate implant placement compared to natural socket healing and increase in the facial bone width is an indication that we may be able to resolve the midfacial recession in most cases with future clinical trials and research. Although the study has shown encouraging results, we still need more randomized clinical trials and long-term studies to confirm the findings of this study.

\section{Summary and recommendations}

Healing after immediate implant placement into the infected sites is no different from normal socket healing in infected sockets. There is some associated shrinkage bucco-lingually and vertically as described by Schropp during a normal socket healing process. This study proves that there will be shrinkage in the size of the healing sockets around immediately after the implant placement into the infected sites. However, the infection is not a contraindication to placing the implants, and there is no significant clinical difference in the way that the gap distance fills with bone around the implant when compared to normal socket healing. Therefore, there is no major disadvantage to placing implants into the infected site until the time the socket is managed well with a good surgical protocol, and the soft tissue remains supported with a well-contoured provisional restoration. Clinicians should utilize this protocol with caution as the principles discussed in this article cannot be applied to every case. Proper diagnosis and planning is key factor to achieve predictable results with this protocol.

\section{Acknowledgments}

The author would like to acknowledge contributions made to this study by Mr. Deepjot Singh Saini MPH., MS Fisheries and Mariculture from Texas A\&M University-Corpus Christi, for statistical analysis and Dr. Kavita Dharmaskar, Associate Professor., McMaster University, Staff Radiologist, Department of Diagnostic Imaging, Juravinski Hospital and Cancer Centre, Hamilton Health Sciences, 711 Concession Street, Hamilton, ON, Canada, for reviewing the Cone Beam CT readings.

\section{References}

1. Adell R, Lekholm U, Rockler B, Branemark PI (1981)A 15-year study of osseointegrated implants in the treatment of the edentulous jaw. Int J Oral Surg 10: 387-416. [Crossref]

2. Quirynen M, Gijbels F, Jacobs R (2003) An infected jawbone site compromising successful osseointegration. Periodontol 2000 33: 129-144. [Crossref]

3. Ayangco L, Sheridan PJ (2001) Development and treatment of retrograde periimplantitis involving a site with a history of failed endodontic and apicoectomy procedures: a series of reports. Int J Oral Maxillofac Implants 16: 412-417. [Crossref]

4. Quirynen M, Vogels R, Alsaadi G, Naert I, Jacobs R, et al. (2005) Predisposing conditions for retrograde peri-implantitis, and treatment suggestions. Clin Oral Implants Res 16: 599-608. [Crossref]

5. Brisman DL, Brisman AS, Moses MS (2001) Implant failures associated with asymptomatic endodontically treated teeth. J Am Dent Assoc 132: 191-195. [Crossref]

6. Siqueira JF Jr, Rocas IN, Oliveira JC, Santos KR (2001) Molecular detection of blackpigmented bacteria in infections of endodontic origin. J Endod 27: 563-566. [Crossref]

7. Sunde PT, Tronstad L, Eribe ER, Lind PO, Olsen I (2000) Assessment of periradicular microbiota by DNA-DNA hybridization. Endod Dent Traumatol 16: 191-196. [Crossref] 
8. Siqueira JF Jr, Roças IN, Oliveira JC, Santos KR (2001) Molecular detection of blackpigmented bacteria in infections of endodontic origin. J Endod 27: 563-566. [Crossref]

9. Ayangco L, Sheridan PJ (2001) Development and treatment of retrograde periimplantitis involving a site with a history of failed endodontic and apicoectomy procedures: a series of reports. Int J Oral Maxillofac Implants 16: 412-417. [Crossref]

10. Sae-Lim V, Metzger Z, Trope M (1998) Local dexamethasone improves periodontal healing of replanted dogs' teeth. Endod Dent Traumatol 14: 232-236. [Crossref]

11. Peters LB, Wesselink PR, van Winkelhoff AJ (2002) Combinations of bacterial species in endodontic infections. Int Endod J 35: 698-702. [Crossref]

12. Lindeboom JA, Tjiook Y, Kroon FH (2006) Immediate placement of implants in periapical infected sites: a prospective randomized study in 50 patients. Oral Surg Oral Med Oral Pathol Oral Radiol Endod 101: 705-710. [Crossref]

13. Villa R, Rangert B (2005) Early loading of interforaminal implants immediately installed after extraction of teeth presenting endodontic and periodontal lesions. Clin Implant Dent Relat Res 7: S28-S35. [Crossref]

14. Casap N, Zeltser C, Wexler A, Tarazi E, Zeltser R (2007) Immediate placement of dental implants into debrided infected dentoalveolar sockets. J Oral Maxillofac Surg 65: 384-392. [Crossref]

15. Lindeboom JA, Tjiook Y, Kroon FH (2006) Immediate placement of implants in periapical infected sites: a prospective randomized study in 50 patients. Oral Surg Oral Med Oral Pathol Oral Radiol Endod 101: 705-710. [Crossref]

16. Pecora G, Andreana S, Covani U, De Leonardis D, Schifferle RE (1996) New directions in surgical endodontics; immediate implantation into an extraction site. $J$ Endod 22 : 135-139. [Crossref]

17. Tripodakis AP (2001) Sofortimplantation in infizierte und defekte Extraktionsalveolen und kontrollierte Sofortimplantatbe- lastung. Teil 1: Einzelzahnimplantate. Implantologie 9: 13-25.

18. Tripodakis AP (2002) Sofortimplantation in infizierte und defekte Extraktionsalveolen und kontrollierte Sofortimplantatbe- lastung. Teil 2: Mehrere benachbarte Zähne. Implantologie 10: 271-286.

19. Rabel A, Kohler SG (2006) Mikrobiologische Untersuchung zur Ermittlung des Erfolges der Sofortimplantation im paro- dontal geschädigten Gebiss. Mund Kiefer Gesichtschir 10: 7-13.

20. Siegenthaler DW, Jung RE, Holderegger C, Roos M, Hammerle CH (2007) Replacement of teeth exhibiting periapical pathology by immediate implants: a prospective, controlled clinical trial. Clin Oral Implants Res 18: 727-737. [Crossref]

21. Villa R, Rangert B (2007) Immediate and early function of implants placed in extraction sockets of maxillary infected teeth: a pilot study. J Prosthet Dent 97: S96-96S108. [Crossref]

22. Kusek ER (2011) Immediate implant placement into infected sites: bacterial studies of the Hydroacoustic effects of the YSGG laser. J Oral Implantol 37: 205-211. [Crossref]

23. Truninger TC, Philipp AO, Siegenthaler DW, Roos M, Hämmerle CH, et al. (2011) A prospective, controlled clinical trial evaluating the clinical and radiological outcome after 3 years of immediately placed implants in sockets exhibiting periapical pathology. Clin Oral Implants Res 22: 20-27.

24. Fugazzotto $P$ (2012) A retrospective analysis of immediately placed implants in 418 sites exhibiting periapical pathology: results and clinical considerations. Int J Oral Maxillofac Implants 27: 194-202. [Crossref]

25. Fugazzotto PA (2012) A retrospective analysis of implants immediately placed in sites with and without periapical pathology in sixty-four patients. J Periodontol 83: 182-186. [Crossref]

26. Jung RE, Zaugg B, Philipp AO, Truninger TC, Siegenthaler DW, et al. (2012) A prospective, controlled clinical trial evaluating the clinical radiological and aesthetic outcome after 5 years of immediately placed implants in sockets exhibiting periapical pathology. Clin Oral Implants Res.

27. Del Fabbro M, Boggian C, Taschieri S (2009) Immediate implant placement into fresh extraction sites with chronic periapical pathologic features combined with plasma rich in growth factors: preliminary results of single-cohort study. J Oral Maxillofac Surg 67: 2476-2484. [Crossref]

28. Bell CL, Diehl D, Bell BM, Bell RE (2011) The immediate placement of dental implants into extraction sites with periapical lesions: a retrospective chart review. $J$ Oral Maxillofac Surg 69: 1623-1627. [Crossref]

29. Jofre J, Valenzuela D, Quintana P, Asenjo-Lobos C (2012) Protocol for immediate implant replacement of infected teeth. Implant Dent 21: 287-294. [Crossref]

30. Meltzer AM (2012) Immediate implant placement and restoration in infected sites. Int
J Periodontics Restorative Dent 32: e169-173. [Crossref]

31. Rosenquist B, Grenthe B (1996) Immediate placement of implants into extraction sockets: implant survival. Int J Oral Maxillofac Implants 11: 205-209. [Crossref]

32. Quirynen M, Gijbels F, Jacobs R (2003) An infected jawbone site compromising successful osseointegration. Periodontol 2000 33: 129-144. [Crossref]

33. Werbitt MJ, Goldberg PV (1992) The immediate implant: bone preservation and bone regeneration. Int J Periodontics Restorative Dent 12: 206-217. [Crossref]

34. Becker W, Becker BE (1990) Guided tissue regeneration for implants placed into extraction sockets and for implant dehiscences: surgical techniques and case report. Int J Periodontics Restorative Dent 10: 376-391. [Crossref]

35. Barzilay I (1993) Immediate implants: their current status. Int J Prosthodont 6: 169175. [Crossref]

36. Polizzi G, Grunder U, Goené R, Hatano N, Henry P, et al. (2000) Immediate and delayed implant placement into extraction sockets: a 5-year report. Clin Implant Dent Relat Res 2: 93-99. [Crossref]

37. Ayangco L, Sheridan PJ (2001) Development and treatment of retrograde periimplantitis involving a site with a history of failed endodontic and apicoectomy procedures: a series of reports. Int J Oral Maxillofac Implants 16: 412-417. [Crossref]

38. Evian CI, Emling R, Rosenberg ES, Waasdorp JA, Halpern W, et al. (2004) Retrospective analysis of implant survival and the influence of periodontal disease and immediate placement on long-term results. Int J Oral Maxillofac Implants 19: 393-398. [Crossref]

39. Wagenberg B, Froum SJ (2006) A retrospective study of 1925 consecutively placed immediate implants from 1988 to 2004. Int J Oral Maxillofac Implants 21: 71-80. [Crossref]

40. Horwitz J, Zuabi O, Machtei E (2008) Radiographic changes around immediately restored dental implants in periodontally susceptible patients: 1-year results. Int J Oral Maxillofac Implants 23: 531-538. [Crossref]

41. Deng F, Zhang H, Zhang H, Shao H, He Q, et al. (2010) A comparison of clinical outcomes for implants placed in fresh extraction sockets versus healed sites in periodontally compromised patients: a 1-year follow-up report. Int J Oral Maxillofac Implants 25: 1036-1040. [Crossref]

42. Saito H, Chu SJ, Reynolds MA, Tarnow DP (2016) Provisional restorations used in immediate implant placement provide a platform to promote peri-implant soft tissue healing: apilot study. Int J Periodontics Restorative Dent 36: 47-52. [Crossref]

43. Somerman MJ, Archer SY, Imm GR, Foster RA (1988) A comparative study of human periodontal ligament cells and gingival fibroblasts in vitro. $J$ Dent Res 67: 66-70. [Crossref]

44. Yamashita Y, Sato M, Noguchi T (1987) Alkaline phosphatase in the periodonta ligament of the rabbit and macaque monkey. Arch Oral Biol 32: 677-678. [Crossref]

45. McCulloch CA, Bordin S (1991) Role of fibroblast subpopulations in periodontal physiology and pathology. J Periodontal Res 26: 144-154. [Crossref]

46. McCulloch CA (1995) Origins and functions of cells essential for periodontal repair: the role of fibroblasts in tissue homeostasis. Oral Dis 1: 271-278. [Crossref]

47. Lin WL, McCulloch CA, Cho MI (1994) Differentiation of periodontal ligamen fibroblasts into osteoblasts during socket healing after tooth extraction in the rat. Anat Rec 240: 492-506. [Crossref]

48. Ahn JJ, Shin HI (2008) Bone tissue formation in extraction sockets from sites with advanced periodontal disease: a histomorphometric study in humans. Int J Oral Maxillofac Implants 23: 1133-1138. [Crossref]

Copyright: (C2017 Panjali A. This is an open-access article distributed under the terms of the Creative Commons Attribution License, which permits unrestricted use, distribution, and reproduction in any medium, provided the original author and source are credited. 